This is a pre-print of an article published in Review of Managerial Science.

The final authenticated version is available online at:

https://link.springer.com/article/10.1007\%2Fs11846-019-00355-2\#citeas

\title{
Impact of mission statement components on social enterprises' performance
}

\author{
Jasmina Berbegal-Mirabent \\ Marta Mas-Machuca \\ Patricia Guix \\ Universitat Internacional de Catalunya
}

\begin{abstract}
Social enterprises mix economic and social objectives, forming a bridge between non-profit and profit enterprises. Mission statements are a strategic tool that can provide a company with a purpose of being, a "being" that communicates the core of the business to internal and external stakeholders. In this paper we aim to investigate the link between mission statements and performance in social enterprises. The sample includes 39 social enterprises located in Spain. Our findings indicate that those firms for which the mission statement explicitly considers the customers and the product/service offer are more likely to exhibit higher economic performance.
\end{abstract}

Keywords: social enterprises, mission statement, qualitative comparative analysis, performance.

JEL: C35, L19, L31

\section{Introduction}

The concept of social enterprise (SE) is quite new and, during the past 20 years, has gained increasing interest in various regions of the world (Defourny and Nyssens 2010, 2012; Kraus et al. 2014). In Europe the notion of SE first appeared during the 1980s, but the term started to be used in the 1990s. This type of company is situated within the third sector, settled between the market, public policies, and civil societies (Defourny and Nyssens 2006). As expressed by Sassmannshausen and Volkmann (2018: 1), "in a world that faces many social challenges and with governments that are often unable to provide solutions, motivated social 
entrepreneurs are often key to improving socially challenging situations." The increased number of research networks and academic forums in the field of social entrepreneurship and social enterprise further confirm the growing interest in this topic among scholars and practitioners (Kraus et al. 2017).

Although there is no commonly agreed definition of SE (Alegre et al. 2017), two main schools of thoughts are identified (Dees and Anderson 2006). On the one hand, according to the Social Enterprise School of Thought, social enterprises are defined as organisations that are orientated towards the market with the purpose of following an earnedincome strategy to serve a social mission. On the other hand, the Social Innovation School defines social enterprises as organisations that respond to social problems or meet social needs. For the purpose of this study, we use the definition provided by Di Domenico et al. (2010: 683), which not only has achieved a sound reputation among scholars but also seems to effectively intertwine the two aforementioned perspectives (Social Enterprise School of Thought and Social Innovation School). According to these authors, social enterprises are "organisations that seek to attain a particular social objective or set of objectives through the sale of products and/or services, and in doing so aim to achieve financial sustainability independent of government and other donors." Further, this definition is consistent with the European ${ }^{1}$ concept of SE, that is, organisations that pursue a social mission and have an explicitly economic rationale.

One of the main leaders for the initial empowerment of SE during the 1990s was the EMES European Research Network, ${ }^{2}$ which conducted the first theoretical and empirical analysis of SE (Borzaga and Defourny 2001). According to the EMES, social enterprises

\footnotetext{
${ }^{1}$ https://ec.europa.eu/growth/sectors/social-economy/enterprises_en

2 EMES: EMergence des Enterprises Sociales en Europe. The acronym is in French because the first research project was carried out in France, and the acronym was retained when the network decided to become international (www.emes.net).
} 
should ideally address two main objectives: 1) economic, that is, the continuous activity of producing and selling goods and services, a high degree of autonomy, a significant level of economic risk, and a minimum amount of paid work; and 2) social, an explicit aim to benefit the community, an initiative launched by a group of citizens, decision-making power that is not based on capital, a participatory nature, and limited profit distributions. Said differently, compared to traditional companies, SE incorporate elements from different institutional logics (Battilana and Dorado 2010; Pache and Santos 2010) as they pursue a social objective through commercial activities. This hybrid nature is somehow mirrored in the mission statements of SE.

Mission statements play a relevant part in the formulation of companies' strategy (O’Gorman and Doran 1999; Sidhu 2003), facilitating strategy implementation by encouraging the unity of purpose of the firm and motivation towards the mission (Bartkus and Glassman 2008; Campbell and Yeung 1991). Mission statements are worthwhile for having a clear idea of what an organisation wants to be and whom it wants to serve. Drucker (1973: 61) defined a mission statement as "the foundation for priorities, strategies, plans, and work assignments. It is the starting point for the design of jobs and organisational structures. Nothing may seem simpler or more obvious than to know what a company's business is. A lumber mill makes lumber, an airline carries passengers and freight, and a bank lends money. But 'What is our business?' is almost always a difficult question and the right answer is usually anything but obvious. The answer to this question is the first responsibility of strategists." For years the academic and managerial literature has suggested that a mission statement provides benefits that originate economic and financial value (see Alegre et al. (2018) for a comprehensive review of the literature). 
In the last decade, increased attention has been paid to the study of the mission in non-profit organisations (Kirk and Nolan 2010; Patel et al. 2015). For these organisations Moss et al. (2011) suggest that the mission statement should explicitly include the social contribution as well as the economic viability, reflecting both a utilitarian and a normative organisational identity. Recent research suggests that, in the third sector, creating and implementing a mission statement helps to achieve organisational success. As Pandey et al. (2017: 389) state, the "passion for a cause is crucial: however, passion alone cannot build and sustain organisations."

Organisations that simultaneously pursue both a social mission and an economic rationale display a mission-market tension, which is an everyday practical concern for managers (Sanders 2015; Wijesiri et al. 2017). Acknowledging this duality, this study focuses on how SEs articulate their mission statement and if the way they do it has an impact on their financial performance. To this end, we examine whether there are some specific combinations of components of a mission statement that should be included when defining the mission of a SE in order to achieve better performance. The empirical application considers a sample of 39 social enterprises located in Spain. In a first stage, we undertake a content analysis of the mission statement of the selected ventures. Next, we conduct a qualitative comparative analysis (QCA) aimed at identifying potential combinations of mission components linked to superior economic performance (measured in terms of return on assets and net income). This method has been proven to be suitable for this type of analysis as shown in recent works on entrepreneurship and innovation (e.g. Cruz-Ros et al. 2018; Kraus et al. 2018).

This study contributes to the existing literature in three main ways. First, we shed new light on the inconclusive existing works exploring the relationship between mission 
statements and performance. Second, while previous works on mission statements have mainly focused on for-profit ventures (e.g. Pearce and David 1987), non-profit organisations (e.g. Kirk and Nolan 2010; Patel et al. 2015), healthcare institutions (e.g. Bart 2007; Bart and Tabone 1998, 1999, 2000; Macedo et al. 2016), we add new evidences from SEs, a type of organisation that is attracting increased attention among academics and policymakers. Third, we use qualitative comparative analysis. This technique is particularly useful here given that it analyses configurations of factors (mission statement components) associated with an outcome (economic performance of the firm) and can readily take account of the ways in which factors interact with each other. This method has been found to work particularly well with small samples, as is our case.

The remainder of this article is structured as follows. First, we summarise previous works scrutinising the potential association between mission statements and firm performance. Next we describe the method and data used for the empirical analysis. Then we present the results and discuss the main implications. The article concludes by highlighting the main takeaways of the study and suggesting new avenues for future research.

\section{Theoretical background}

Drucker (1973: 3), known as the founder of modern management, said that "the first job of the leader is to think through and define the mission of the institution." A mission statement is formed on the basis of the values, purpose, and beliefs shared by the firm's employees (Collins and Porras 2005). Usually it is defined as a formal document that describes the distinct and enduring purpose of an organisation (Desmidt et al. 2011).

Though what should be written in the mission statement of a company? The review of the literature reveals that there is no unique way to define or create a mission statement, 
and there is no agreement on the components that a mission statement should have. In this sense, different authors have studied the importance of defining a mission statement in an effective way (Bart 1997; David 1989; Kemp and Dwyer 2003; Morris 1996). Abell (1980) was one of the first authors to study mission components and concluded that mission statements should indicate who the satisfied customers are, what their needs are, and how these needs should be satisfied. After Abell's contribution other attempts appeared, trying to be more precise concerning the components to be included. One of the seminal works is the one by Pearce and David (1987). According to these authors, a mission statement differentiates among eight components: customers, products and services, location, core technology, company philosophy, company self-concept, public image and concern for survival, and growth and profitability. Some years later Bart (1997) adopted a new approach according to the stakeholder theory and identified five components: customers, employees, investors, suppliers, and society.

In a recent study, Rey and Bastons (2018) suggest a new holistic conceptualisation of the mission statement. Three dimensions are considered: 1) mission as a formal statement, 2) mission as dynamic practices, and 3) mission as a source of motivation. Based on this framework, the definition of a mission statement in a social venture is a key issue, as its articulation reflects the essence of the organisation. Although in a social venture the social element is typically included in the mission statement, there are other aspects, such as products and services, market or growth related to its implementation, that tend to also appear (Suh et al. 2011). This means that SEs must align their internal processes with the social objectives. This is particularly relevant as it reflects the extent to which the firm is adjusting its performance to what it is stated in its mission. 
The wide popularity of mission statements within strategic planning might be due to the different benefits that mission statements might give to an organisation. Among others are the following: (1) provide a sense of the firm's direction and purpose (Bart et al. 2001); (2) focus on the allocation of organisational resources (Barktus et al. 2000); (3) communicate effectively with internal and external stakeholders (Barktus et al. 2000); and (4) guide and motivate employees (Collins and Porras 2005). Yet, there is a lack of empirical evidence to suggest that having a mission statement implies better financial performance. Aiming to disentangling this relationship, several authors have investigated the impact of mission statements on organisational performance, with the latter typically interpreted as financial outcome (e.g. Alawneh 2015; Bart and Baetz 1998; Bart et al. 2001; Dermol 2012; Palmer and Short 2008; Sidhu 2003). Inconclusive results are, however, reported, mainly due to how performance is measured (Alegre et al. 2018). Also, the specific features of the industries under analysis make results difficult to be compared.

According to Ward (2015), the relationship between the content of a company's mission statement and its organisational performance can be explained by signalling theory. This theory is suitable in situations of asymmetric information (Connelly et al. 2011). In the realm of corporate reporting, signalling theory suggests that high-performing organisations will be more likely to disclose information in the areas in which they excel and to pursue a strategy of transparency as a way to attract investors, enhance public image and motivate their staff. Therefore, it is believed that high-performing organisations will have more comprehensive mission statements. As such, it is not surprising that previous studies analysing firm performance have focused on how organisations define themselves.

In the specific context of SE, there are scarce studies addressing this relationship, and those doing so mainly refer to the public healthcare industry and include not-for-profit 
organisations (Bart 2007; Bart and Tabone 1998, 1999, 2000). Other relevant studies include the work of Kirk and Nolan (2010) who conducted an exploratory study to examine the relationship between mission statement attributes and organisational financial performance in women's rights' non-profit organisations. The results show that mission statements with a more focused geographic scope were associated with lower results. In contrast, mission statements that included the target and customers were associated with better performance. Similarly, Patel et al. (2015) studied the relationship between the mission statements and the performance of non-profit organisations. The results lend support to a positive relationship. Furthermore, the findings suggest that a positive moderator for this relationship is organisational commitment ${ }^{3}$ meaning that more commitment leads to a better impact of the mission on performance. Along the same lines, Macedo et al. (2016) conducted a quantitative study of 112 non-profit healthcare organisations in Portugal. The findings show a positive direct link between mission statement and performance. They also concluded that organisational commitment is an important mediator in the linkage between mission and performance. Finally, more recently, Pandey et al. (2017) conducted a text analysis to measure the mission statement attributes of activity and commonality to improve performance. The authors suggested an association between mission statements' semantic attributes and non-profit performance.

Table 1 summarises the main studies that connect mission statement with performance in non-profit organisations.

Insert Table 1 about here

\footnotetext{
3 Organisational commitment: "How an individual feels towards their organisation in terms of emotional attachment, acceptance of goals and values, identification with the organisation, behavioural investments and wanting to stay in the organisation" (Patel et al. 2015: 761).
} 


\section{Methodology}

\subsection{Sample and data}

For the purpose of this study, the analysis focuses on mission statements from Spanish social enterprises. Following Bartkus et al. (2006), we adopted a broad definition of a mission statement, that is, when the mission statement of a company has at least some of the following elements: purpose, goals, product markets, and values/philosophical views. Similar to other studies (Mas-Machuca et al. 2017) when a company has more than one statement, we choose the statement labelled as "mission."

The sample for our study includes prestigious Spanish social enterprises that received awards between 2011 and 2014 in Spain, thanks to national social projects. The awards were given by Program Gencat, La Caixa, Ashoka, Emprenedoria Social de la Fundació, and the Momentum Project. The selection of winners followed a rigorous process, as the enterprises participating in this project had to indicate clearly how they create a positive impact on society. A total of 187 companies fulfilled this requirement.

For each company, information of interest was gathered from different sources. Data referring to the descriptive characteristics of the company were obtained from their websites (legal form, social objective, founding date, location, sector, and number of employees). The mission statement was also taken from the website. As some relevant information was missing, 70 companies were dropped from the initial sample. Lastly, information concerning economic and financial performance was obtained from the SABI (System of Analysis of Iberian Balances). Following Waddock and Graves (1997) and Barnett and Salomon (2012), financial performance is measured employing two of the most used metrics: the net income and the return on assets (ROA). Additional data were collected manually by contacting the Department of Justice. Unfortunately, few companies in which we were interested had 
published such information. Thus, the final sample was reduced to 39 social enterprises, yet the database contains reliable information. The SEs in our sample are characterised as relatively small (average number of employees is 28.38 , with the exception of a large company with 237 employees) and fairly mature in the marketplace (average age of 14). As for the legal form, the sample is quite balanced with $54 \%$ of them being foundations or associations and the remaining $46 \%$ being limited liability companies (SL, using the Spanish notation) or public limited companies (SA).

\subsection{Content analysis}

In the first-stage analysis, we explored which components were included in the mission statements of the selected companies. Content analysis was the method chosen, as it allows for the analysis of a written message (Moss et al. 2011). Specifically, we followed the works of Bart (1997) and Pearce and David (1987) in scrutinising the presence of mission statements" components and stakeholders, respectively. A value of "1" was given when the component or stakeholder (see Table 2) was present in the mission and "0" otherwise. Three independent researchers performed the analysis. The inter-rater reliability coefficient was calculated as 0.813 , denoting consistency among observational ratings provided by multiple coders. The final evaluation was based on the majority of the rater decisions.

Insert Table 2 about here

\subsection{Qualitative comparative analysis}

Given the reduced sample size and the purpose of this study - that is, to investigate which combinations of mission statements' components and stakeholders are more likely to lead to 
better performance - in the second stage, we chose qualitative comparative analysis (QCA) as the most suitable technique for conducting the empirical study. QCA was developed by Ragin (1987) and is a data analysis technique. This method not only allows for the identification of conditions to explain an outcome but is also found to perform well with reduced samples, such as the one that we have. Furthermore, QCA adopts a double perspective that combines qualitative and quantitative elements. QCA focuses on relationships that detect the configurations that produce a specific outcome. These configurations are based on a combination of variables (called antecedent conditions) that can be positive, negative, or absent.

QCA uses combinatorial logic to work out which combinations of case characteristics may be necessary or sufficient to produce an outcome. The first step when using this method is to transform (calibrate) variables into fuzzy or crisp sets. For categorical or dummy variables, we calibrate variables using crisp sets. Crisp sets fix the value of 1 for those variables that are full members of a given category and 0 to indicate non-membership. Alternatively, for continuous variables, fuzzy sets are preferred. In the latter case, it is possible to indicate the degrees of membership of a given category. Furthermore, it introduces the value 0.5 , meaning the point with maximum ambiguity. Table 3 shows how the variables have been transformed. The percentiles 10, 50, and 90 were used as thresholds for full non-membership (0.05), cross-over point (0.5), and full membership (0.95), respectively.

Insert Table 3 about here 
As can be seen in Table 3, besides the inclusion of mission statement components as antecedent conditions, three additional controls were considered, namely size, age, and legal form. These three variables are expected to shape the financial performance of the company and consequently contribute to the emergence of different patterns.

Before proceeding with the analysis, a study of the necessity has to be performed for each individual antecedent condition on the outcome of interest. As we had two different outcomes, we conducted this analysis twice. None of the antecedent conditions showed a consistency score exceeding the threshold value of 0.9 (Schneider et al. 2010); therefore, our approach was correct.

The next step consisted of running the models. Using Boolean algebra, the QuineMcCluskey algorithm computes the commonalities among the configurations that lead to the outcome and generates a logical reduction of statements (Quine 1952,1955). The reduction is based on two parameters: coverage, which indicates the empirical relevance of a solution, and consistency, denoting the extent to which cases sharing similar conditions display the same outcome. A minimum consistency of 0.8 and coverage of 0.45 are sufficient to indicate goodness of fit (Ragin 2008).

Four different models were tested. Models 1 and 2 focused on the components defined by Pearce and David (1987), being net profit, the outcome in Model 1, and ROA, the outcome in Model 2. Similarly, Models 3 and 4 used Bart's (1997) stakeholders. The outcomes were net profit in Model 3 and ROA in Model 4. Following Baumgartner (2015), in this paper we report the intermediate solution. The results are presented as suggested by Ragin and Fiss (2008), in which “•” represents the presence of the condition, “ $\bigcirc$ " indicates its absence, and blank spaces denote ambiguity of the condition. 


\section{Results and discussion}

Table 4 displays the results when considering the components outlined by Pearce and David (1987). Following Ragin's (2008) recommendation, for each model we focus our attention on the two causal paths with the highest raw coverage. Accordingly, four configurations are displayed, two for each outcome. As can be observed, different pathways can be followed to obtain the desired outcome. For Model 1 the solution consistency is 0.9225 , and the solution coverage is 0.6168 . The values for Model 2 are 0.8667 and 0.5405 , respectively. In all instances the values are above the advisable threshold values ( 0.8 and 0.45 , respectively); consequently, the approach is suitable. Likewise, in all four recipes that emerged from the analysis, the consistency scores are above 0.8 , and the raw coverage values are high, indicating that the data adjusted well to the configurations.

Insert Table 4 about here

Turning to the specificity of the results, our findings reveal that, regardless of the metric used to operationalise the financial performance (either through the net income or through the ROA), the results are quite similar. Specifically, the components that are worth mentioning in the mission statement in order to bring about higher performance rates are the product/service offer and the customers. This holds true for companies with solid experience in the market, particularly for large companies regardless of their legal form (see configurations \#1 and \#3). For small SEs, focussing attention on the customer, which might signal that the company customises the product/service according to the specific requirements of the client, is recommended. None of the remaining components are 
recommended for inclusion. Results also indicate that small and young companies perform better if they are established legally as a foundation or an association (see configuration \#4). On the contrary, for small but consolidated firms, SL or SA are the preferred legal forms (configuration \#2).

Analogously, Table 5 reports the results when examining which stakeholders (according to Bart 1997) are worth mentioning in the mission statement. Again, four configurations arise: two for Model 3 (outcome: net income) and two for Model 4 (outcome: ROA). All four configurations (\#5 to \#8) converge in that customers are key stakeholders to be cited. Large and consolidated companies should mirror configuration \#5, particularly if they are constituted as a SA or SL. Besides emphasising the customers, these companies should also make sure that their mission statement specifies how the company generates value for the general society. For small companies, configurations \#6 and \#7 with a strong customer-oriented focus are recommended. Again, the results reveal that measuring performance through different metrics does not make a big difference, as the results are fairly similar (expect for configuration \#5).

Insert Table 5 about here

Because QCA permits the analysis of cases, it is possible to identify which observations (in our case social enterprises) best fit each configuration. Thus, given the results and taking all the configurations together, it is possible to suggest some recommendations based on two of the variables included in the model: size and age - note that the legal form seems not to be that determinant when creating patterns. Specifically, the 
social enterprises from our sample can be categorised into three main groups (see Figure 1 for a graphical representation): 1) large and consolidated companies, 2) small but consolidated companies, and 3) small and young companies.

Insert Figure 1 about here

For companies in group 1, configurations \#1,\#3, and \#5 are worthy of analysis in greater detail. For instance, an example of a company that matches this profile is a social enterprise established in Barcelona in 1996, whose mission clearly mirrors the results reported in our analysis: "willingness to help all those people who are at risk of social exclusion (people from a penitentiary environment, without resources, unemployed, with physical disabilities, etc.) giving them the possibility of having a job that allows them this social and labour inclusion." As is shown, the mission primarily focuses on the customers (people at risk of social exclusion) and explicitly articulates how the organisation will accomplish its goal (the service offer), in this case, by offering a job. Another example that falls within this group is a foundation created in 1987, with more than 20 employees and a presence in different regions across Spain (Madrid, Valencia, and Catalunya). Its mission is formulated as follows: "our mission is to fight against the loneliness and social marginalisation of the elderly, through the voluntary action of volunteers who accompany them and the sensitisation of society." In this case this mission not only highlights the customer (the elderly) and the service offer (voluntary action to fight against loneliness and social marginalisation) but also self-reflection about the impact on society (sensitisation of society). Therefore, this company fits well with configuration \#5. Overall, we can conclude that large and consolidated social enterprises should pay special attention to customers, the 
product/service offer and society. This way, the mission statement is explicitly marketoriented, clearly defining what they can offer, to whom, and how the company creates value to society.

For companies in group 2 (small but consolidated), configuration \#2 would be the best benchmark. Note that this configuration only applies to companies that are established under the legal form of a SA or SL. One example of a firm within this group is a small company constituted as a limited society that was established in 1996 and operates in the audiovisual sector. Its mission is to "contribute to the enrichment of society through social documentaries." As observed, the mission does not mention who the customer is but states what the core offer is (that is, social documentaries). Looking at other companies that fall within this group, it can be inferred that the main focus is placed on enhancing the product/service offer. Accordingly, efforts should be directed towards raising market awareness.

Lastly, companies in group 3 (small and young) are represented by configurations \#4 and \#6. In this case the mission should be mainly customer focused, avoiding references to other stakeholders. A social enterprise that participated in the Momentum Project and was established in 2014 is an archetype of the companies within this group. With two employees, this company operates in Madrid, and its core objective is "providing training and employment to women in situations of social exclusion." In this case the mission clearly refers to the customers (i.e. women in situations of social exclusion), and the service offer is also clearly stated (i.e. providing training and employment). A similar behaviour is observed in other companies that belong to this group. Because these companies are still at an early stage of development, their main goal is to survive. To do so it is important to clearly 
indicate in their mission statement who the potential recipients of their product/service offers are.

Finally, it is remarkable that any of the other Pearce and David's (1987) components (location, technology, growth and public image) appear to be relevant. Similarly, investors and suppliers, based on Bart's components (1997), should also be avoided when articulating the mission statement. This result is congruent with the work of Mas-Machuca et al. (2017) who found that mission statements of Spanish SE tend to emphasise customers and products/services. Our study adds value to this work by confirming that these two elements are associated with superior economic performance. On the contrary, our results do not find convincing empirical evidence that company's philosophy-another common element as identified in Mas-Machuca et al. (2017)—results in improved financial performance.

\section{Concluding remarks}

The financial performance of a company is important to keep the firm active in the marketplace. Nowadays SEs do not tend to survive as long as more traditional enterprises, mainly because they do not have the same financial opportunities. Previous studies have revealed that it is difficult to converge on a definition of a SE (Alegre et al., 2018) and, that to some extent, many of today's commercial business models are also based on ideas with a social intention, which further complicates the establishment of a common framework for the understanding and definition of SE (Halberstadt and Kraus 2016). Within this context, there is a theoretical and empirical need to explore whether there is a connection between companies' mission statements and their financial performance. Our analysis tries to address both issues by examining the relationship between the mission statements and the performance of SEs. 
For a SE the definition of the mission statement is of paramount importance. The mission is full of connotation about the intentions of the company. Given the social impact these companies are expected to have, how they explicitly communicate it to both internal and external stakeholders makes a big difference. According to Rey and Bastons (2018) it is relevant to consider the mission as a formal statement, as a dynamic process and as a source of motivation. Furthermore, as Costanzo et al. (2014) point out, the hybrid nature of SE also gives birth to a dual tension in the components of the corporate mission. In their seek for business solutions to social problem, social enterprises should also be economically sustainable, meaning that they should equally compete in the marketplace for resources and customers as any other type of firm. The mission statement is a useful tool where to summarise how they balance this double objective.

Based on the results from our analysis we conclude that there are some components of mission statements that seem to have a positive impact on the financial performance of this particular type of firms. As expressed by Pearce and David (1998), perhaps it is too ambitious to prove a direct financial consequence. However, after the research we can provide evidence of a relationship between mission statements and performance, depending on which configuration of components is used. Even though we examined the mission using two different approaches (following Bart's stakeholders (1997) and Pearce and David's (1987) mission components) and considered two different outcomes (net income and ROA), the results obtained point in the same direction, thereby endorsing their consistency. As such, two main conclusions can be drawn. First, as revealed by the different configurations obtained, SEs that economically succeed follow different strategies. Said differently, not all components of mission statements are equally important; it depends on how they are combined, and they are also highly dependent on the characteristics of SE (e.g. small/large, new/old, etc.). In Figure 1 we have provided a characterisation that SEs might find useful 
when setting their goals. Second, among the different mission components, SEs should preferably focus their attention on two of them: customers and the product/service offer.

Furthermore, from a detailed analysis of the companies in our sample, our results seem to suggest that, when formulating the mission statement, young SEs should pay special attention to the customer, and, as the company gains experience or expands its size, they should also focus on the product/service that it is offering.

This study provides the existing literature with new insights in two key ways. First, it contributes to the field of social entrepreneurship. The results presented are expected to help this type of enterprise to balance the profitability-social dilemma better. Second, this study adds value to the mission statement literature by shedding new light on the relationship between economic performance and strategic management (that is, how to define and articulate the ultimate goal of a company).

As any other academic study, this article presents some limitations that constitute new avenues for future research. First, although QCA performs well with small samples, it would be worth enlarging the sample. Second, due to the lack of financial information, we were only able to use two metrics to evaluate the economic performance of a company. Likewise, performance could also be operationalised though other metrics, not just those referring to economic performance. In this sense, future studies might consider not only measuring economic performance but also social impact. Third, future studies are needed to understand better the direct and indirect effects between mission statements and performance, specifically in SE, in which mission statements are essential and inherent in the definition of the business. 


\section{References}

Abell DF (1980) Defining the business: The starting point of strategic planning. PrenticeHall, Englewood Cliffs.

Alawneh AA (2015) The impact of mission statement on performance: An exploratory study in the Jordanian banking industry. J Manage Policy Pract 16(4):73-87.

Alegre I, Berbegal-Mirabent J, Guerrero A, Mas-Machuca M (2018) The real mission of the mission statement: A systematic review of the literature. J Manage Organ 24(4):456473.

Alegre I, Kislenko S, Berbegal-Mirabent, J (2017) Organized chaos: Mapping the definitions of social entrepreneurship. J Soc Entrep 8(2):248-264.

Barnett ML, Salomon RM (2012) Does it pay to be really good? Addressing the shape of the relationship between social and financial performance. Strategic Manage J 33(11), $1304-1320$.

Bart CK (2007) A comparative analysis of mission statement content in secular and faithbased hospitals, J Intellect Cap 8(4):682-694.

Bart CK (1997) Sex, lies and mission statements. Bus Horizons 40(6):9-18.

Bart CK, Baetz M (1998) The relationship between mission statements and firm performance: an exploratory study. J Manage Stud 35(6):823-853.

Bart CK, Bontis N, Taggar S (2001) A model of the impact of mission statements on firm performance. Manage Decis 39(1):19-35.

Bart CK, Tabone JC (2000) Mission statements in Canadian not-for-profit hospitals: Does process matter? Health Care Manage R 25(2):45-63.

Bart CK, Tabone JC (1999) Mission statement content and hospital performance in the Canadian not-for-profit health care sector. Health Care Manage R 24(3):18-29.

Bart CK, Tabone JC (1998) Mission statement rationales and organizational alignment in the not-for-profit health care sector. Health Care Manage R 23(4):54-69.

Bartkus B, Glassman M (2008) Do firms practice what they preach? The relationship between mission statements and stakeholder management. J Bus Ethics 83(2):207-216.

Bartkus B, Glassman M, McAfee RB (2006) Mission statement quality and financial performance. Eur Manag J 24(1):86-94.

Bartkus B, Glassman M, McAfee RB (2000) Mission Statements: Are they smoke and mirrors? Bus Horizons 43(6):23-28. 
Battilana J, Dorado S (2010) Building sustainable hybrid organizations: The case of commercial microfinance organizations. Acad Manage J 53(6):1419-1440.

Baumgartner M (2015) Parsimony and causality. Qual Quant 49(2):839-856.

Borzaga C, Defourny J (2001) From third sector to social enterprise. Routledge, London.

Campbell A, Yeung S (1991) Creating a sense of mission. Long Range Plann 24(4):10-20.

Collins JC, Porras JI (2005) Built to last: Successful habits of visionary companies. Random House, London.

Connelly BL, Certo ST, Ireland RD, Reutzel CR (2011) Signaling theory: A review and assessment. J Manage 37(1):39-67.

Costanzo LA, Vurro C, Foster D, Servato F, Perrini F (2014) Dual-mission management in social entrepreneurship: Qualitative evidence from social firms in the United Kingdom. J Small Bus Manage 52(4):655-677.

Cruz-Ros S, Guerrero-Sánchez DL, Miquel-Romero MJ (2018) Absorptive capacity and its impact on innovation and performance: findings from SEM and fsQCA. Rev Manag Sci, 1-15. DOI: 10.1007/s11846-018-0280-5.

David F (1989) How companies define their mission. Long Range Plann 22(1):90-97.

Dees JG, Anderson BB (2006) Framing a theory of social entrepreneurship: building on two schools of practice and thought. Research on social entrepreneurship: Understanding and contributing to an emerging field 1(3):39-66.

Defourny J, Nyssens M (2012) The EMES approach of social enterprise in a comparative perspective. EMES European Research Network, WP no. 12/03.

Defourny J, Nyssens M (2010) Conceptions of social enterprise and social entrepreneurship in Europe and the United States: Convergences and divergences. J Soc Entrep 1(1):3253.

Defourny J, Nyssens M (2006) Defining social enterprise. In: Nyssens M (ed) Social enterprise: At the crossroads of market, public policies and civil society. Routledge Taylor \& Francis Group, London, pp 3-27.

Dermol V (2012) Relationship between mission statement and company performance. Annals of the Alexandru Ioan Cuza University-Economics, 59(1):321-336.

Desmidt S, Prinzie A, Decramer A (2011) Looking for the value of mission statements: A meta-analysis of 20 years of research. Manage Decis 49(3):468-483.

Di Domenico M, Haugh H, Tracey P (2010) Social bricolage: Theorizing social value creation in social enterprises. Entrep Theory Pract 34(4):681-703. 
Drucker P (1973) Management: Tasks, responsibilities, and practices. Harper \& Row, New York.

Halberstadt J, Kraus, S (2016) Social entrepreneurship: The foundation of tomorrow's commercial business models? Int Journal of Entrepren Venturing, 8(3), 261-279.

Kemp S, Dwyer L (2003) Mission statements of international airlines: A content analysis. Tourism Manage 24(6):635-653.

Kirk G, Nolan SB (2010) Nonprofit mission statement focus and financial performance. Nonprofit Manag Lead 20(4):473-490.

Kraus S, Filser M, O’Dwyer M, Shaw E (2014) Social entrepreneurship: An exploratory citation analysis. Rev Manag Sci 8(2):275-292.

Kraus S, Niemand T, Halberstadt J, Shaw E, Syrjä P (2017) Social entrepreneurship orientation: Development of a measurement scale. Int J Entrepren Behav \& Res 23(6), 977-997.

Kraus S, Ribeiro-Soriano D, Schüssler M (2018) Fuzzy-set qualitative comparative analysis (fsQCA) in entrepreneurship and innovation research-the rise of a method. Int Entrepren Manage J 14(1), 15-33.

Macedo IM, Pinho JC, Silva AM (2016) Revisiting the link between mission statements and organizational performance in the non-profit sector: The mediating effect of organizational commitment. Eur Manag J 34(1):36-46.

Mas-Machuca M, Ballesteros-Sola M, Guerrero A (2017) Unveiling the mission statements in social enterprises: A comparative content analysis of US vs Spanish-based organizations. J Soc Entrep 8(2):186-200.

Morris RJ (1996) Developing a mission for a diversified company. Long Range Plann 29(1):103-115.

Moss TW, Short JC, Payne GT, Lumpkin GT (2011) Dual identities in social ventures: An exploratory study. Entrep Theory Pract 35(4):805-830.

O’Gorman C, Doran R (1999) Mission statements in small and medium-sized businesses. J Small Bus Manage 37(4):59-66.

Pache AC, Santos F (2010) When worlds collide: The internal dynamics of organizational responses to conflicting institutional demands. Acad Manage Rev 35(3):455-476.

Palmer TB, Short JC (2008) Mission statements in US colleges of business: An empirical examination of their content with linkages to configurations and performance. Acad Mange Learn Edu 7(4):454-470.

Pandey S, Kim M, Pandey SK (2017) Do mission statements matter for nonprofit performance? Nonprofit Manag Lead 27(3):389-410. 
Patel BS, Booker LD, Ramos HM, Bart C (2015) Mission statements and performance in non-profit organisations. Corp Gov 15(5):759-774.

Pearce JA, David F (1987) Corporate mission statements: The bottom line. Acad Manage Exec 1(2):109-116.

Rey C, Bastons M (2018) Three dimensions of effective mission implementation. Long Range Plann 51(4):580-585.

Quine WV (1955) A way to simplify truth functions. Am Math Mon 62(9):627-631.

Quine WV (1952) The problem of simplifying truth functions. Am Math Mon 59(8):521531.

Ragin CC (2008) Redesigning social inquiry: Fuzzy sets and beyond. University of Chicago Press, Chicago.

Ragin CC (1987) The comparative method: Moving beyond qualitative and quantitative strategies. University of California Press, Oakland, California.

Ragin CC, Fiss P (2008) Net effects analysis versus configurational analysis: An empirical demonstration. In: Ragin CC (ed) Redesigning social inquiry: Fuzzy sets and beyond. University of Chicago Press, Chicago, pp 190-212.

Sanders ML (2015) Being nonprofit-like in a market economy: Understanding the missionmarket tension in nonprofit organizing. Nonprof Volunt Sec Q 44(2):205-222.

Sassmannshausen SP, Volkmann C (2018) The scientometrics of social entrepreneurship and its establishment as an academic field. J Small Bus Manage 56(2):251-273.

Schneider MR, Schulze-Bentrop C, Paunescu M (2010) Mapping the institutional capital of high-tech firms: A fuzzy-set analysis of capitalist variety and export performance. $\mathrm{J}$ Int Bus Stud 41(2):246-266.

Sidhu J (2003) Mission statements: Is it time to shelve them? Eur Manag J 21(4):439-446.

Suh T, Houston MB, Barney SM, Kwon IWG (2011) The impact of mission fulfillment on the internal audience: Psychological job outcomes in a services setting. J Serv Res-US 14(1):76-92.

Waddock SA, Graves SB (1997) The corporate social performance-financial performance link. Strategic Manage J 18(4):303-319

Ward RE (2015) Buried accomplishments: Institutional isomorphism in college athletics mission statements. Int J Sport Com 8 18-45.

Wijesiri M, Martínez-Campillo A, Wanke P (2017) Is there a trade-off between social and financial performance of public commercial banks in India? A multi-activity DEA model with shared inputs and undesirable outputs. Rev Manage Sci 13(2):417-442. 


\section{List of Figures}

Figure 1. Configurations that explain firm performance.

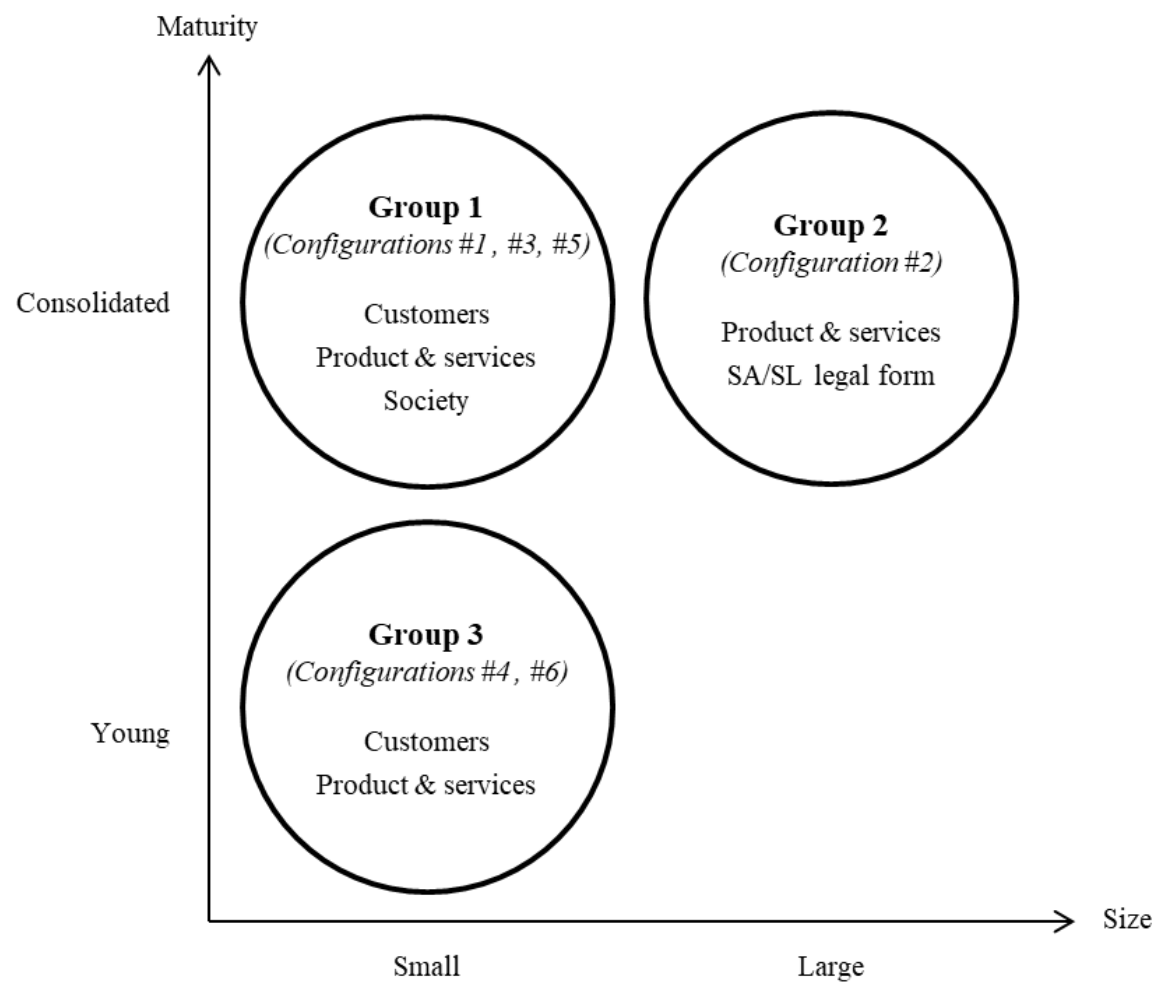




\section{List of Tables}

Table 1. Relevant research examining the relationship between mission statements and performance in non-profit organizations

\begin{tabular}{|c|c|c|c|c|c|}
\hline Authors & Year & Title & Journal & Sample & Conclusions \\
\hline $\begin{array}{l}\text { Bart and } \\
\text { Tabone }\end{array}$ & 1998 & $\begin{array}{l}\text { Mission statement } \\
\text { rationales and } \\
\text { organizational } \\
\text { alignment in the not- } \\
\text { for-profit health care } \\
\text { sector }\end{array}$ & $\begin{array}{l}\text { Health Care } \\
\text { Management } \\
\text { Review }\end{array}$ & $\begin{array}{l}103 \text { Canadian } \\
\text { hospitals }\end{array}$ & $\begin{array}{l}\text { Some of the rationales for } \\
\text { developing mission statements } \\
\text { are indeed more important than } \\
\text { others. Mission statement } \\
\text { alignment with organizational } \\
\text { structures is central to the } \\
\text { mission's success. }\end{array}$ \\
\hline $\begin{array}{l}\text { Bart and } \\
\text { Tabone }\end{array}$ & 1999 & $\begin{array}{l}\text { Mission statement } \\
\text { content and hospital } \\
\text { performance in the } \\
\text { Canadian non-profit } \\
\text { health care sector }\end{array}$ & $\begin{array}{l}\text { Health Care } \\
\text { Management } \\
\text { Review }\end{array}$ & $\begin{array}{l}103 \text { Canadian } \\
\text { hospitals }\end{array}$ & $\begin{array}{l}\text { There is a positive relationship } \\
\text { between selected mission } \\
\text { statement components and some } \\
\text { performance indicators. }\end{array}$ \\
\hline $\begin{array}{l}\text { Bart and } \\
\text { Tabone }\end{array}$ & 2000 & $\begin{array}{l}\text { Mission statements in } \\
\text { Canadian not-for-profit } \\
\text { hospitals: Does process } \\
\text { matter }\end{array}$ & $\begin{array}{l}\text { Health Care } \\
\text { Management } \\
\text { Review }\end{array}$ & $\begin{array}{l}103 \text { Canadian } \\
\text { hospitals }\end{array}$ & $\begin{array}{l}\text { There is a relationship between } \\
\text { selected mission process } \\
\text { characteristics and measures of } \\
\text { performance. }\end{array}$ \\
\hline Bart & 2007 & $\begin{array}{l}\text { A comparative analysis } \\
\text { of mission statement } \\
\text { content in secular and } \\
\text { faith-based hospitals }\end{array}$ & $\begin{array}{l}\text { Journal of } \\
\text { Intellectual } \\
\text { Capital }\end{array}$ & $\begin{array}{l}130 \text { top } \\
\text { managers } \\
\text { from } 515 \\
\text { Canadian } \\
\text { hospitals }\end{array}$ & $\begin{array}{l}\text { Dissimilarities in mission content } \\
\text { exist between different types of } \\
\text { hospitals. These differences form } \\
\text { a pattern of sorts within each } \\
\text { type. }\end{array}$ \\
\hline $\begin{array}{l}\text { Kirk and } \\
\text { Nolan }\end{array}$ & 2010 & $\begin{array}{l}\text { Non-profit mission } \\
\text { statement focus and } \\
\text { financial performance }\end{array}$ & $\begin{array}{l}\text { Nonprofit } \\
\text { Management } \\
\text { and } \\
\text { Leadership }\end{array}$ & $\begin{array}{l}138 \text { women's } \\
\text { rights non- } \\
\text { profit } \\
\text { organizations } \\
\text { (WNPOs) }\end{array}$ & $\begin{array}{l}\text { Mission statements with a more } \\
\text { focused geographic scope are } \\
\text { associated with lower overhead } \\
\text { ratios. In contrast, mission } \\
\text { statements with different target } \\
\text { client groups have larger one- } \\
\text { year increases in contribution. }\end{array}$ \\
\hline $\begin{array}{l}\text { Patel, } \\
\text { Booker, } \\
\text { Ramos, and } \\
\text { Bart }\end{array}$ & 2015 & $\begin{array}{l}\text { Mission statements and } \\
\text { performance in non- } \\
\text { profit organizations }\end{array}$ & $\begin{array}{l}\text { Corporate } \\
\text { Governance }\end{array}$ & $\begin{array}{l}117 \\
\text { respondents } \\
\text { of non-profit } \\
\text { organizations } \\
\text { from } 30 \\
\text { countries }\end{array}$ & $\begin{array}{l}\text { For non-profit organizations } \\
\text { there is a positive relationship } \\
\text { between performance and } \\
\text { mission statements. }\end{array}$ \\
\hline $\begin{array}{l}\text { Macedo, } \\
\text { Pinho, and } \\
\text { Silva }\end{array}$ & 2016 & $\begin{array}{l}\text { Revisiting the link } \\
\text { between mission } \\
\text { statements and } \\
\text { organizational } \\
\text { performance in the non- } \\
\text { profit sector: The } \\
\text { mediating effect of } \\
\text { organizational } \\
\text { commitment }\end{array}$ & $\begin{array}{l}\text { European } \\
\text { Management } \\
\text { Journal }\end{array}$ & $\begin{array}{l}112 \\
\text { Portuguese } \\
\text { non-profit } \\
\text { health care } \\
\text { organizations }\end{array}$ & $\begin{array}{l}\text { The relationship between } \\
\text { mission statements and } \\
\text { organizational performance is } \\
\text { better understood if the influence } \\
\text { of organizational commitment, as } \\
\text { a mediating variable of the } \\
\text { aforementioned relationship, is } \\
\text { taken into account. }\end{array}$ \\
\hline $\begin{array}{l}\text { Pandey, } \\
\text { Kim, and } \\
\text { Pandey }\end{array}$ & 2017 & $\begin{array}{l}\text { Do mission statements } \\
\text { matter for non-profit } \\
\text { performance? }\end{array}$ & $\begin{array}{l}\text { Nonprofit } \\
\text { Management } \\
\text { and } \\
\text { Leadership }\end{array}$ & $\begin{array}{l}\text { US } \\
\text { Performing } \\
\text { arts } \\
\text { organizations }\end{array}$ & $\begin{array}{l}\text { Mission statement attribute } \\
\text { activity is associated with } \\
\text { improved performance for both } \\
\text { instrumental and expressive } \\
\text { function. }\end{array}$ \\
\hline
\end{tabular}


Table 2. List of components taken into account in the study

\begin{tabular}{|c|c|c|}
\hline \multirow{6}{*}{ 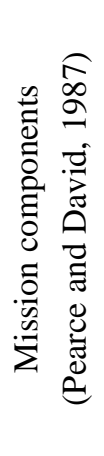 } & Customer & $\begin{array}{l}\text { Target customer and market. For whom are we carrying out } \\
\text { our activity? }\end{array}$ \\
\hline & Products and services & Commitment to the primary products or services \\
\hline & Location/market & $\begin{array}{l}\text { Specify the firm's intended geographic domain for marketing } \\
\text { in which the company competes }\end{array}$ \\
\hline & Technology & Description of the firm's core technologies \\
\hline & $\begin{array}{l}\text { Concern for survival, growth, and } \\
\text { profitability }\end{array}$ & Desire to increase or target levels of growth \\
\hline & Concern for public image & Response to social and environmental concerns \\
\hline \multirow{5}{*}{ 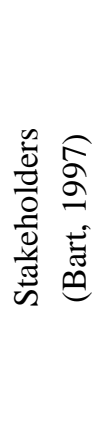 } & Customers & $\begin{array}{l}\text { Target customer and market. For whom are we carrying out } \\
\text { our activity? }\end{array}$ \\
\hline & Employees & $\begin{array}{l}\text { Person who contributes labor or expertise to the social } \\
\text { enterprise }\end{array}$ \\
\hline & Investors & $\begin{array}{l}\text { External person who invests in the company and cares about } \\
\text { the performance }\end{array}$ \\
\hline & Suppliers & $\begin{array}{l}\text { Providers of products or services who care about the business } \\
\text { working }\end{array}$ \\
\hline & Society & External stakeholder who may have an effect of the business \\
\hline \multirow{3}{*}{ 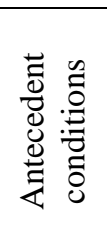 } & Legal form ${ }^{*}$ & Different legal statuses: SA, SL, foundations, or associations \\
\hline & Age & $\begin{array}{l}\text { Accounts for the expertise of the business. The foundation } \\
\text { date ranges from } 1972 \text { to } 2014\end{array}$ \\
\hline & Num. of employees & $\begin{array}{l}\text { Considers the size of the business. In our sample this number } \\
\text { ranges between } 1 \text { and } 237 \text { employees }\end{array}$ \\
\hline \multirow{2}{*}{ 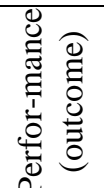 } & Economic profitability (ROA) & Return on assets calculated as net income / assets \\
\hline & Net income (profit) & $\begin{array}{l}\text { Total profit of a company. It is calculated by taking the } \\
\text { revenues and deducting the business costs plus depreciation, } \\
\text { interest, or taxes }\end{array}$ \\
\hline
\end{tabular}

${ }^{*}$ SA: anonymous society, SL: limited society. 
Table 3. Variable definition and calibration values

\begin{tabular}{|c|c|c|c|c|}
\hline Antecedent Condition & Description & $\begin{array}{l}\text { Full Non- } \\
\text { membership } \\
(\mathbf{0 . 0 5})\end{array}$ & $\begin{array}{l}\text { Crossover } \\
\text { Point } \\
(0.5)\end{array}$ & $\begin{array}{c}\text { Full } \\
\text { Membership } \\
(\mathbf{0 . 9 5 )}\end{array}$ \\
\hline Customer* & \multirow{10}{*}{$\begin{array}{l}\text { Is the factor on the } \\
\text { mission statement } \\
(1=\text { yes; } 0=\text { no })\end{array}$} & 0 & & 1 \\
\hline Products and services & & 0 & & 1 \\
\hline Location/market & & 0 & & 1 \\
\hline Technology & & 0 & & 1 \\
\hline $\begin{array}{l}\text { Concern for survival, growth, } \\
\text { and profitability }\end{array}$ & & 0 & & 1 \\
\hline Concern for public image & & 0 & & 1 \\
\hline Employee & & 0 & & 1 \\
\hline Investor & & 0 & & 1 \\
\hline Supplier & & 0 & & 1 \\
\hline Society & & 0 & & 1 \\
\hline Legal form & $\begin{array}{l}\text { Legal status }(1=\mathrm{SL} \text { or } \\
\mathrm{SA} ; 0=\text { foundation or } \\
\text { association) }\end{array}$ & 0 & & 1 \\
\hline Employees** & $\begin{array}{l}\text { Number of employees } \\
\text { of the social enterprise }\end{array}$ & 1.10 & 10.10 & 74.10 \\
\hline $\operatorname{Age}^{* *}$ & Age of the firm & 4.60 & 9.90 & 30.40 \\
\hline Net income ${ }^{* *}$ & Net income & $-77,282.36$ & $2,041.23$ & $51,693,83$ \\
\hline Economic profitability** & Return on assets & -0.243 & 0.063 & 1.581 \\
\hline
\end{tabular}

* This antecedent condition is the same for both the Pearce and David (1987) and the Bart (1997) classification scheme.

** Variables expressed in fuzzy-set terms. The data refer to the year 2014. 
Table 4. Sufficient configurations of antecedent conditions for performance, according to Pearce and David (1987)

\begin{tabular}{|c|c|c|c|c|c|c|c|c|c|c|c|c|c|}
\hline \multirow[b]{2}{*}{ Outcome } & \multirow[b]{2}{*}{$\begin{array}{c}\text { Configuration } \\
\text { No. } \\
\end{array}$} & \multicolumn{6}{|c|}{ Mission Components } & \multicolumn{3}{|c|}{ Control } & \multicolumn{2}{|c|}{ Coverage } & \multirow[b]{2}{*}{ Consistency } \\
\hline & & 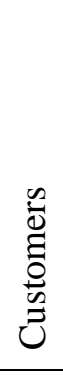 & 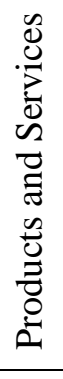 & 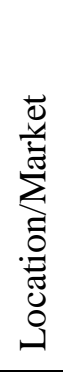 & 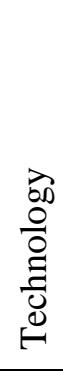 & 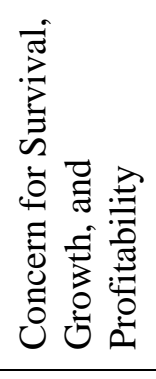 & 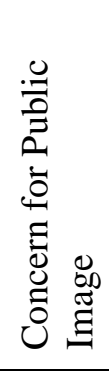 & $\stackrel{\tilde{N}}{\mathrm{n}}$ & $\underset{8}{\infty}$ & 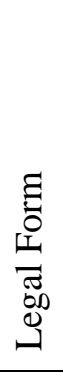 & Raw & Unique & \\
\hline \multirow{3}{*}{$\begin{array}{l}\text { Model 1: } \\
\text { Net } \\
\text { Income }\end{array}$} & $\# 1$ & $\bullet$ & $\bullet$ & O & O & O & o & $\bullet$ & $\bullet$ & & 0.2930 & 0.2082 & 0.9000 \\
\hline & $\# 2$ & & $\bullet$ & 0 & ○ & 0 & o & o & $\bullet$ & $\bullet$ & 0.1204 & 0.7050 & 0.8838 \\
\hline & \multicolumn{13}{|c|}{$\begin{array}{l}\text { Solution coverage: } 0.6168 \\
\text { Solution consistency: } 0.9225\end{array}$} \\
\hline \multirow{3}{*}{$\begin{array}{l}\text { Model 2: } \\
\text { ROA }\end{array}$} & $\# 3$ & $\bullet$ & $\bullet$ & 0 & o & 0 & o & $\bullet$ & $\bullet$ & & 0.3063 & 0.2035 & 0.8247 \\
\hline & $\# 4$ & $\bullet$ & $\bullet$ & o & o & o & o & o & o & ○ & 0.1138 & 0.0739 & 0.8703 \\
\hline & \multicolumn{13}{|c|}{$\begin{array}{l}\text { Solution coverage: } 0.5405 \\
\text { Solution consistency: } 0.8667\end{array}$} \\
\hline
\end{tabular}


Table 5. Sufficient Configurations of Antecedent Conditions for Performance, according to Bart (1997)

\begin{tabular}{|c|c|c|c|c|c|c|c|c|c|c|c|c|}
\hline \multirow[b]{2}{*}{ Outcome } & \multirow[b]{2}{*}{$\begin{array}{c}\text { Configuration } \\
\text { No. }\end{array}$} & \multicolumn{5}{|c|}{ Mission Stakeholders } & \multicolumn{3}{|c|}{ Control } & \multicolumn{2}{|c|}{ Coverage } & \multirow[b]{2}{*}{ Consistency } \\
\hline & & $\begin{array}{l}\tilde{\omega} \\
\tilde{\Xi} \\
0 \\
\tilde{0} \\
\tilde{U}\end{array}$ & $\begin{array}{l}\tilde{\Xi} \\
\stackrel{0}{0} \\
\frac{0}{0} \\
\text { : }\end{array}$ & 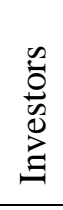 & 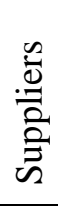 & $\begin{array}{l}\overrightarrow{2} \\
\frac{0}{0} \\
0 \\
i\end{array}$ & $\stackrel{\tilde{N}}{2}$ & $\underset{\&}{\infty}$ & 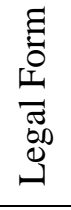 & Raw & Unique & \\
\hline \multirow{2}{*}{$\begin{array}{l}\text { Model 3: } \\
\text { Net } \\
\text { Income }\end{array}$} & \#6 & $\bullet$ & ० & ○ & $\circ$ & 0 & 0 & 0 & & 0.1329 & 0.0201 & 0.8711 \\
\hline & \multicolumn{12}{|c|}{$\begin{array}{l}\text { Solution coverage: } 0.5444 \\
\text { Solution consistency: } 0.9161\end{array}$} \\
\hline \multirow{3}{*}{$\begin{array}{l}\text { Model 4: } \\
\text { ROA }\end{array}$} & $\# 7$ & $\bullet$ & ○ & O & 0 & $\circ$ & $\circ$ & & $\bullet$ & 0.1346 & 0.1346 & 0.9647 \\
\hline & \#8 & $\bullet$ & 0 & 0 & 0 & 0 & & O & 0 & 0.0925 & 0.0700 & 0.8848 \\
\hline & \multicolumn{12}{|c|}{$\begin{array}{l}\text { Solution coverage: } 0.4612 \\
\text { Solution consistency: } 0.9398\end{array}$} \\
\hline
\end{tabular}

